\title{
Double-blind study of erbium 169 injection (synoviorthesis) in rheumatoid digital joints
}

\author{
C.-J. MENKES, A. LE Gô, P. VERRIER, M. AIGNAN, AND F. DELBARRE \\ From Institut de Rheumatologie, Unité 5 INSERM, CNRS ERA 337, and Laboratoire d'Explorations \\ Fonctionnelles par les Radio-Isotopes, Hôpital Cochin, Paris
}

SUMMARY A double-blind study of erbium 169 injection into rheumatoid digital joints was carried out with saline as control. 201 joints in 36 patients were studied (137 metacarpophalangeal, $64 \frac{\varrho}{2}$ proximal interphalangeal). Erbium 169 was injected into 121 joints and saline water into 80 joints. $\dot{\omega}$ Local injection of corticosteroids was given to both groups. A definite improvement was observed $\omega$ in $55 \%$ to $58 \%$ of cases with erbium 169 (+ prednisolone acetate) and in $26 \%$ to $28 \%$ of cases with $\mathcal{N}^{\circ}$ saline (+prednisolone acetate). The difference was highly significant.

Intra-articular injection of radioisotopic $\beta$ emitter is used to control synovial inflammation and to prevent osteoarticular damage, or is given when drug therapy has failed (Ansell et al., 1963; Makin et al., 1963.) New isotopes have been developed that permit treatment of any inflamed joint whether joint effusion is present or not (Table 1) (Delbarre et al., 1972; Gumpel, 1973). Yttrium $90\left({ }^{90} \mathrm{Y}\right)$ has a high penetrating capacity and is used mainly for the treatment of the knee joint in rheumatoid arthritis. A double-blind study has proved the effectiveness of ${ }^{90} \mathrm{Y}$ as compared to saline water and nonradioactive yttrium (Delbarre et al., 1974).

Smaller joints such as the wrist, elbow, shoulder, ankle, or hip can be treated with gold $198\left({ }^{198} \mathrm{Au}\right)$, or better with rhenium $186\left({ }^{186} \mathrm{Rh}\right)$ which is an almost pure $\beta$ emitter (Delbarre et al., 1973). For the small digital joints, erbium $169\left({ }^{169} \mathrm{Er}\right)$ has been chosen. It is a radioisotopic $\beta$ emitter of limited effect and penetration.

A large clinical trial with 1261 digital joints treated with ${ }^{169} \mathrm{Er}$ between 1969 and 1973 gave very good and good results in $54.6 \%$ of cases after one year (Menkes et al., 1974). As corticosteroid injection was used simultaneously, it was thought necessary to assess the exact therapeutic value of ${ }^{16}{ }^{9} \mathrm{Er}$ using a double-blind study with saline water as control.

\section{Methods}

ISOTOPIC INJECTIONS

The digital joints were randomly allocated to two

Accepted for publication August 17, 1976

Correspondence to Bibliothèque, Clinique de Rhumatologie Médicale et Sociale, Hôpital Cochin, 27 Rue du Faubourg Saint-Jacques, 75674 Paris Cedex 14, France. groups. To prevent transient local reaction after $\vec{\complement}$ isotopic injection, $5 \mathrm{mg}$ prednisolone acetate was added to ${ }^{169} \mathrm{Er}$ and also to saline water. A radio- $\overrightarrow{0}$ scopic control with arthrography was used to be certain that the liquid was within the joint.

The injection dose was $1 \mathrm{mCi}{ }^{16}{ }^{9} \mathrm{Er}$ for the metacarpophalangeal joint (MCP) and $0.5 \mathrm{mCi}{ }^{169} \mathrm{Er}$ for the proximal interphalangeal joint (PIP). Colloidal ${ }^{169} \mathrm{Er}$ citrate, pH 7 (Commissariat à l'énergie atomique-Saclay), was used. The mean $\triangle$ diameter of particules is $100 \AA$ and physical proper- $\overline{0}$ ties of ${ }^{169} \mathrm{Er}$ are given in Table 1 .

The parameters used for comparison between groups were duration of disease, clinical stage, radiological stage, modification of the ESR, and Rose-Waaler test titration.

Each joint was tested for synovial thickness, 을 synovial effusion, and range of movement. Global measure of the joint volume was made with the ring 을 method for PIP joints and with a compass for MCP joints. In most cases patients were re-examined after $ᄋ$ 3 months and then again between 6 months and $1 \frac{D}{9}$ year. The notation was: 'excellent' for an apparently․ㅡㄹ normal joint, 'good' for marked improvement of $N$ subjective parameters and of mobility associated with" decreased joint effusion, 'fair' for improvement of some tests, and 'poor'.

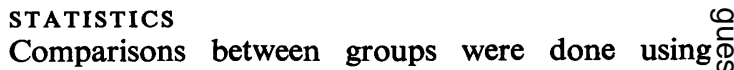
Student's ' $t$ ' and $\chi^{2}$ tests. All the binary coded data ${ }^{\text {' }}$ were processed on 36091 IBM computer* using $\frac{T}{0}$ principal components multifactorial analysis. These $\frac{\overrightarrow{\mathbb{D}}}{\mathrm{D}}$

*Centre d'Etudes Nucléaires - Fontenay-aux-Roses, Prof $\stackrel{\mathbb{D}}{\stackrel{0}{ }}$ Roucayrol. 
Table 1 Isotopes used for synoviorthesis

\begin{tabular}{|c|c|c|c|c|c|c|c|}
\hline \multirow{2}{*}{ Isotope } & \multirow{2}{*}{$\begin{array}{l}\text { Duration } \\
\text { (d) }\end{array}$} & \multirow{2}{*}{$\begin{array}{l}\text { Type of } \\
\text { radiation }\end{array}$} & \multirow{2}{*}{$\begin{array}{l}\text { Maximum } \\
\text { energy of } \\
\text { radiation }(\mathrm{MeV})\end{array}$} & \multicolumn{2}{|c|}{ Tissue penetration $(\mathrm{mm})$} & \multicolumn{2}{|c|}{ Cartilage penetration } \\
\hline & & & & Mean & Maximal & Mean & Maximal \\
\hline${ }^{169} \mathrm{Er}$ & $9 \cdot 5$ & $\begin{array}{l}\boldsymbol{\beta} \\
\gamma \\
\beta\end{array}$ & $\begin{array}{l}0 \cdot 34 \\
0 \cdot 03 \\
0 \cdot 96\end{array}$ & $0 \cdot 3$ & 1 & $0 \cdot 2$ & $0 \cdot 7$ \\
\hline${ }^{198} \mathrm{Au}$ & $2 \cdot 7$ & $\begin{array}{l}\gamma \\
\beta\end{array}$ & 0.41 & $1 \cdot 2$ & $3 \cdot 6$ & 0.9 & $2 \cdot 7$ \\
\hline $\begin{array}{l}{ }^{186} \mathrm{Rh} \\
{ }^{90} \mathrm{Y}\end{array}$ & $\begin{array}{l}3 \cdot 7 \\
2 \cdot 7\end{array}$ & $\gamma$ (rare) & $\begin{array}{l}0 \cdot 98 \\
2 \cdot 2\end{array}$ & $\begin{array}{l}1 \cdot 2 \\
3 \cdot 6\end{array}$ & $\begin{array}{l}3 \cdot 7 \\
11\end{array}$ & $\begin{array}{l}1 \\
2 \cdot 8\end{array}$ & $\begin{array}{l}3 \cdot 1 \\
8 \cdot 5\end{array}$ \\
\hline
\end{tabular}

analyses are designed to work in connection with all parameters and to give a graphic outline of the results.

\section{Patients}

244 digital joints in 41 patients suffering from classical rheumatoid arthritis, according to the American Rheumatic Association criteria, were treated. 201 joints of 36 patients ( 12 had negative latex and Rose-Waaler tests) were studied. The other 5 patients were not studied as medical treatment had to be modified during follow-up (i.e. drug side effects, flare-up of the disease in other joints). ${ }^{169} \mathrm{Er}$ (+prednisolone acetate) was injected into 121 joints, and saline water (+prednisolone acetate) into 80 joints. Of $137 \mathrm{MCP}$ joints, 85 were injected with ${ }^{169} \mathrm{Er}$ and 52 with saline water. Of 64 PIP joints, 36 were injected with ${ }^{169} \mathrm{Er}$ and 28 with saline water.

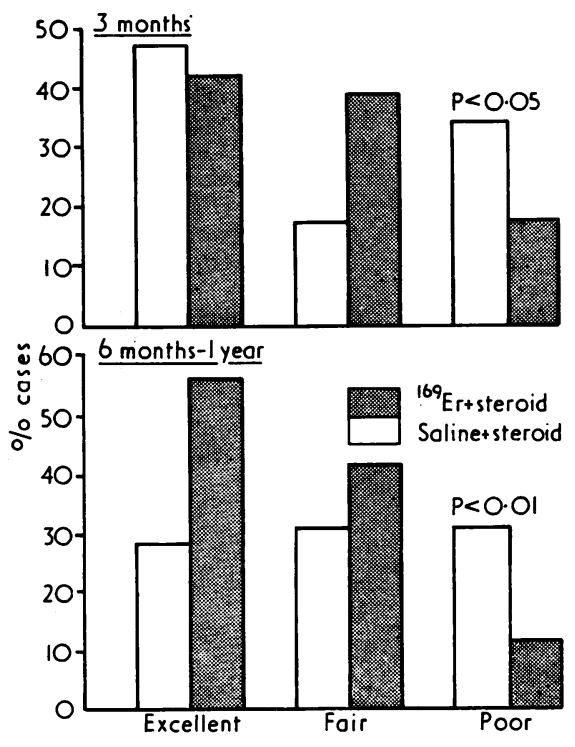

Fig. 1 Results of saline and erbium 169 injection.

\section{Results}

We found no statistically significant difference between the two groups of patients for any parameter before treatment, nor any difference between parameters. But 3 months after the injections there was a significant difference between the two groups with regard to 'poor' results $(35 \%$ injected with saline, $17.8 \%$ injected with ${ }^{169} \mathrm{Er}, \mathrm{P}<0.05$ ). Between 6 months and one year the difference between the two groups was more striking since with ${ }^{169} \mathrm{Er} 58 \%$ 'excellent' or 'good' results were seen compared with only $28.5 \%$ with saline water $(\mathrm{P}<0.01)$ (Fig. 1$)$.

In 27 patients several joints were treated with either ${ }^{169} \mathrm{Er}$ or saline water. Results were excellent or good in $55 \%$ of those treated with ${ }^{169} \mathrm{Er}$ and in

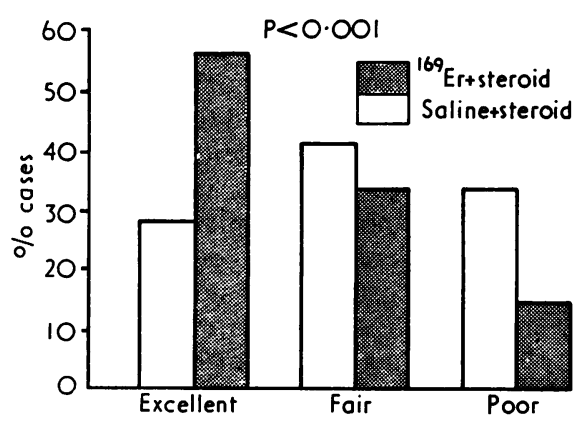

Fig. 2 Comparison of the results in patients treated by both saline and erbium.

Table 2 Changes in results between the 1st estimation ( 3 months) and the 2 nd estimation (6 months-1 year)

\begin{tabular}{|c|c|c|c|c|}
\hline & \multicolumn{2}{|c|}{ Impairment of results } & \multicolumn{2}{|c|}{ Improvement of results } \\
\hline & $\begin{array}{l}\text { Excellent/ } \\
\text { Good }\end{array}$ & $\%$ & Fair/Poor & $\%$ \\
\hline $\begin{array}{l}\text { Saline } \\
16^{9} \mathrm{Er} \\
\mathrm{P}^{*}\end{array}$ & $\begin{array}{l}9 / 18 \\
7 / 26\end{array}$ & $\begin{array}{l}50 \cdot 0 \\
26 \cdot 9 \\
\text { NS }\end{array}$ & $\begin{array}{r}1 / 18 \\
11 / 30\end{array}$ & $\begin{array}{l}5 \cdot 6 \\
36 \cdot 7 \\
<0.02\end{array}$ \\
\hline
\end{tabular}

*Exact probability 
Table 3 Results in ${ }^{169}$ Er-treated patients according to radiological lesions (Steinbrocker classification)

\begin{tabular}{|c|c|c|c|c|c|c|c|}
\hline \multirow{3}{*}{$\begin{array}{l}\text { Steinbrocker } \\
\text { classification }\end{array}$} & \multicolumn{7}{|c|}{ Results } \\
\hline & \multicolumn{2}{|c|}{ Excellent/Good } & \multicolumn{2}{|c|}{ Fair } & \multicolumn{3}{|c|}{ Poor } \\
\hline & $n$ & $\%$ & $n$ & $\%$ & $n$ & $\%$ & \\
\hline $\begin{array}{l}1 \\
2 \\
3+4\end{array}$ & $\begin{array}{l}20 \\
21 \\
27\end{array}$ & $\begin{array}{l}62 \cdot 5 \\
51 \cdot 2 \\
56 \cdot 3\end{array}$ & $\begin{array}{r}9 \\
14 \\
15\end{array}$ & $\begin{array}{l}28 \cdot 1 \\
34 \cdot 2 \\
31 \cdot 3\end{array}$ & $\begin{array}{l}3 \\
6 \\
6\end{array}$ & $\begin{array}{r}9 \cdot 4 \\
14 \cdot 6 \\
12 \cdot 5\end{array}$ & NS \\
\hline
\end{tabular}

only $26.5 \%$ treated with saline. The difference between the two treatments was highly significant $(\mathrm{P}<0.001)$, giving strong evidence for the therapeutic value of ${ }^{169} \mathrm{Er}$ (Fig. 2).

Comparison of the results between the first followup (at 3 months) and the second (at 6 months -1 year) in the same patients shows a marked improvement with time in the joints treated with ${ }^{169} \mathrm{Er}$ $(P<0.02)$. Moreover, impairment of excellent and good results occurs less frequently $(26.9 \%)$ with ${ }^{169} \mathrm{Er}$ than with saline water $(50 \%)$, though the difference is not significant (Table 2).

Usually the results of intra-articular radioactive colloid injection closely parallel the radiological lesions as for synovectomy. Better results are seen when the joint is not destroyed. However, in this study there was no significant difference between subgroups according to the Steinbrocker classification (Table 3).

The graphic outlines of multifactorial analysis allow three subgroups of patients to be distinguished according to clinical changes and radiological lesions. The first group includes patients with mild and recent disease, treated with indomethacin, the second group has moderate inflammation, and the third group represents severe destructive arthritis treated with corticosteroids. In patients who had synoviorthesis with saline water (+prednisolone acetate) there was no significant difference between the 3 groups as far as good results are concerned $(29.6 \%, 28.1 \%$, and $29.4 \%$, respectively). On the contrary, with ${ }^{169} \mathrm{Er}$ (+ prednisolone acetate), the incidence of good results was very high in the first group $(80.7 \%)$ and decreased with severity and duration of the disease $(50 \%$ in the second and $42.4 \%$ in the third group).

\section{Discussion}

The activity of ${ }^{169} \mathrm{Er}$ can be compared to othen radioisotopes which have been proved to be ver色 useful in the management of rheumatoid arthritis A definite improvement was observed in $56 \%$ to $58 \%$ of cases. According to statistical analysis, the improvement rate was significantly higher with ${ }^{16}{ }^{9} \mathrm{E} \hat{b}$ compared to corticosteroid therapy with saline water. The doses chosen $(1 \mathrm{mCi}$ for $\mathrm{MCP}$ joints $0.5 \mathrm{mCi}$ for PIP joints) seemed to be optimal, a least for moderately inflamed joints.

\section{References}

Ansell, B. M., Crook, A., Mallard, J. R., and Bywater: E. G. L. (1963). Evaluation of intra-articular colloida gold $\mathrm{Au} 198$ in the treatment of persistent knee effusions Annals of the Rheumatic Diseases, 22, 435-439.

Delbarre, F., Menkes, C. J., Roucayrol, J. C., and Ingranch J. (1972). Les synoviorthèses, p. 171. F.D.P., Paris.

Delbarre, F., Menkes, C. J., Aignan, M., Roucayrol, J. C? Ingrand, J., and Sanchez, A. (1973). Une nouvell: préparation radio-active pour la synoviorthèse: le Rhéniurm 186 colloïdal. Avantages par rapport au colloïde d'or 198 Nouvelle Presse Médicale, 2, 1372.

Delbarre, F., Le Gô, A., Menkes, C. J., and Aignan, M: (1974). Preuve par étude statistique 'en double aveugle' do l'effet thérapeutique d'un colloïde chargé d'Yttrium radiø̄ actif $(90 \mathrm{Y})$ dans l'arthrite rhumatoïde du genou. Comptes Rendus Hebdomadaires des Séances de l'Académie de Sciences; D: Sciences Naturelles (Paris), 279, 1051-1054 Gumpel, J. M. (1973). Symposium on radioactive colloids in the treatment of arthritis. Annals of the Rheumatie Diseases, 32, Suppl. 1, p. 56.

Makin, M., Robin, G. C., and Stein, J. A. (1963). Radioactive gold in the treatment of persistent synovial effusion Israel Medical Journal, 22, 107-111.

Menkes, C. J., Verrier, P., Le Gô, A., and Delbarre, 五 (1974). Synoviorthèse radio-isotopique des articulation digitales dans la polyarthrite rhumatoïde. Annales do Chirurgie, 28, 883-889. 